\title{
COMIDA, CANTO E DANÇA: A CIRCULAÇÃO DE DONS NA FESTA DO GAMBÁ PARA SÃO BENEDITO
}

\author{
Vanessa Lima Brasil de Figueiredo ${ }^{1}$ \\ Luciana Gonçalves de Carvalho ${ }^{2}$
}

As festas de santo são celebrações populares largamente difundidas no Norte do Brasil, cujo padrão de organização envolve a constante presença de um barracão, ou ramada (motivo pelo qual são também chamadas festas de ramada), mastro(s), juízes, mordomos, procuradores, donos e cuidadores do santo, entre outros elementos. Nelas prevalecem ambientes regidos por ações ritualizadas que propiciam e/ou assinalam encontros entre os humanos, e entre eles e divindades. Esferas vitais do mundo social, constituem ocasiões privilegiadas para a formação e a renovação de vínculos de solidariedade, fé e sociabilidade. Ao mesmo tempo que sublinham a sacralidade das relações sociais, desfazem a vulgar dicotomia sagrado-profano na medida em que valorizam dimensões lúdicas do ato de celebrar, principalmente em práticas de comensalidade, na entoação de ladainhas, em cortejos animados por folias e instrumentos de percussão, em jogos e disputas festivas (Nogueira, 2008; Braga, 2007; Cavalcanti, 2002).

No interior da Amazônia, algumas festas de santo envolvem a execução do gambá, um conjunto de expressões musicais elaboradas em torno de tradições supostamente afro-ameríndias baseadas no toque ritualístico de três tambores feitos de madeira e couro animal. Dependendo das particularidades locais, os toques dos tambores podem ser acompanhados da entoação de folias e músicas para dançar, mas, invariavelmente, estão envolvidos em complexos rituais de trocas materiais e simbólicas, tal como ocorre em Almeirim e Aveiro, no Pará, onde o gambá é dedicado a São Benedito (Vaz Filho, 2010), e em Maués, no Amazonas, onde é realizado para São Pedro (Ávila, 2016).

Em Almeirim, o gambá para São Benedito remonta há cerca de 130 anos, ao longo dos quais vem sendo executado e transmitido por homens e mulheres de várias

\footnotetext{
${ }^{1}$ Universidade Federal do Oeste do Pará, Brasil. Email: vanessalbf@outlook.com ORCID id: https://orcid.org/0000-0001-8399-2612

${ }^{2}$ Universidade Federal do Oeste do Pará, Brasil. Email: luciana.gdcarvalho@gmail.com ORCID id: https://orcid.org/0000-0001-7916-9092
} 
gerações da família Castro, uma família negra oriunda de Gurupá, no Pará. Junto com amigos e parentes, os Castros comandam os ritos durante as festividades de São Benedito, que se estendem por dez dias seguidos na cidade e em comunidades rurais próximas à sede municipal. Tal grupo se compõe de foliões, todos do sexo masculino, e dançarinos de ambos os sexos. Embora indivíduos que não pertençam ao grupo possam fruir o gambá, cantando, dançando e acompanhando-o, a prerrogativa de iniciar, conduzir e encerrar as sessões de canto e dança é dos foliões, a cujas ordens os dançarinos obedecem ritualmente.

A cada dia de festa, o gambá é executado, sobretudo, no âmbito de almoços e jantares ofertados por diversos anfitriões aos foliões de São Benedito. Essas refeições são previamente agendadas, e aqueles que desejam ofertá-las, normalmente como pagamento de promessas, combinam a programação com a família Castro e os organizadores do grupo. À chegada dos foliões, a casa que os acolhe já está preparada para o evento. Na verdade, os anfitriões, na maioria das vezes as mulheres (esposas, filhas, parentas e ajudantes contratadas), já terão investido dois ou três dias na preparação das comidas, tanto as do dia a dia (feijão, arroz, macarrão, carnes, farinha) quanto aquelas que são consideradas típicas (vatapá, galinha caipira, pato no tucupi) ou especiais, por levarem ingredientes consumidos com menos frequência (frutas exógenas e cremes, por exemplo).

As refeições são divididas em duas mesas ou rodadas de serviços. Na primeira, apenas os foliões comem, servindo-se um a um de acordo com a ordem hierárquica vigente entre eles. Ao terminarem de comer, levantam-se e, em retribuição pela comida recebida, tocam dois tambores do conjunto do gambá e cantam o Agradecimento da Mesa, cujos versos dão vivas aos anfitriões. Só então os demais convivas são autorizados a se servirem. Quando todos tiverem terminado a refeição, os foliões arriam os tambores e ensejam uma despedida, agradecendo e dando adeus aos presentes.

Nesse instante, o anfitrião intervém, pedindo-lhes que não partam sem tocar e cantar o gambá. Embora a execução musical esteja subentendida como retribuição à refeição, os foliões fazem-se de rogados e argumentam que a jornada nos dias de festa é extenuante e precisam se preparar para o próximo compromisso, com o que todos fazem sinal de concordância. Porém, diante dos pedidos insistentes do anfitrião e de seus convidados, que são igualmente previstos, eles cedem e retomam os instrumentos musicais, inclusive o tambor maior, que não é usado no Agradecimento da Mesa, para 
iniciar o gambá. Ao som dos primeiros toques e cânticos, os dançarinos e as dançarinas do grupo entram em cena. Em seguida, outros comensais se juntam à dança. O evento é encerrado quando os foliões param de tocar.

Essa sequência de dádivas ritualmente ofertadas e retribuídas se repete, invariavelmente, a cada refeição, ao longo de toda a festa. Nesse período, portanto, comida, canto e dança são dons em intensa circulação, como se pretende mostrar neste ensaio.

Aqui, as fotografias produzidas na festividade de 2017, por ocasião da gravação de um documentário etnográfico, conduzem do primeiro ao último dia do evento, revelando a centralidade da comida nos ritos que o compõem. Os registros partem do levantamento do mastro, muito enfeitado com frutas doadas pelos devotos, e seguem até a sua derrubada, quando todo o alimento é disputado antes mesmo que o tronco chegue ao chão. Nesse percurso, passam por diferentes residências cujos donos ofertaram almoços ou jantares aos foliões de São Benedito, os quais, em troca, fizeram o gambá para sua fruição. Os registros terminam no último almoço do ciclo festivo, servido na casa para a qual o mastro foi levado, onde foi feito o derradeiro gambá do ano.

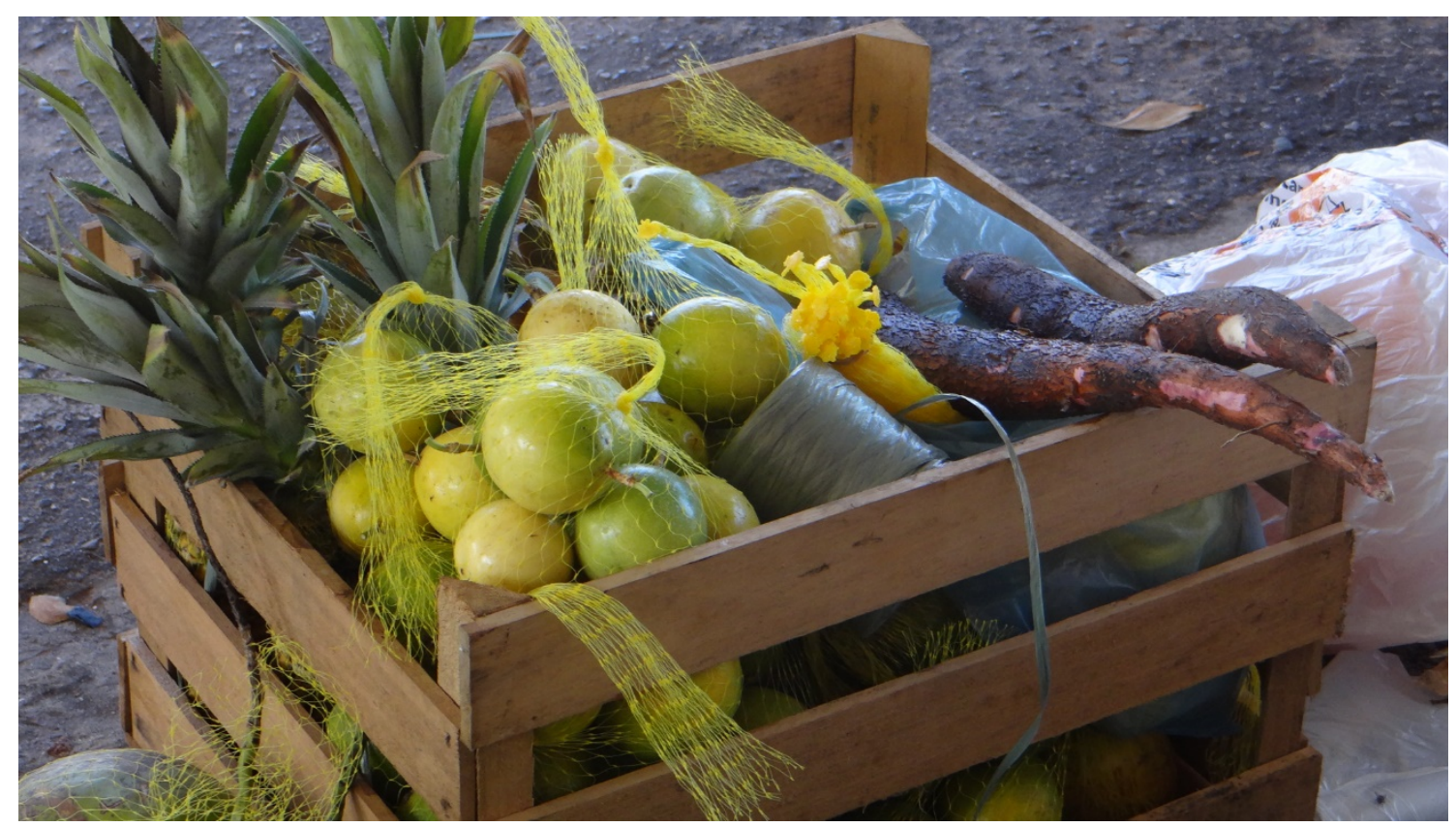


Vanessa Lima Brasil de Figueiredo \& Luciana Gonçalves de Carvalho

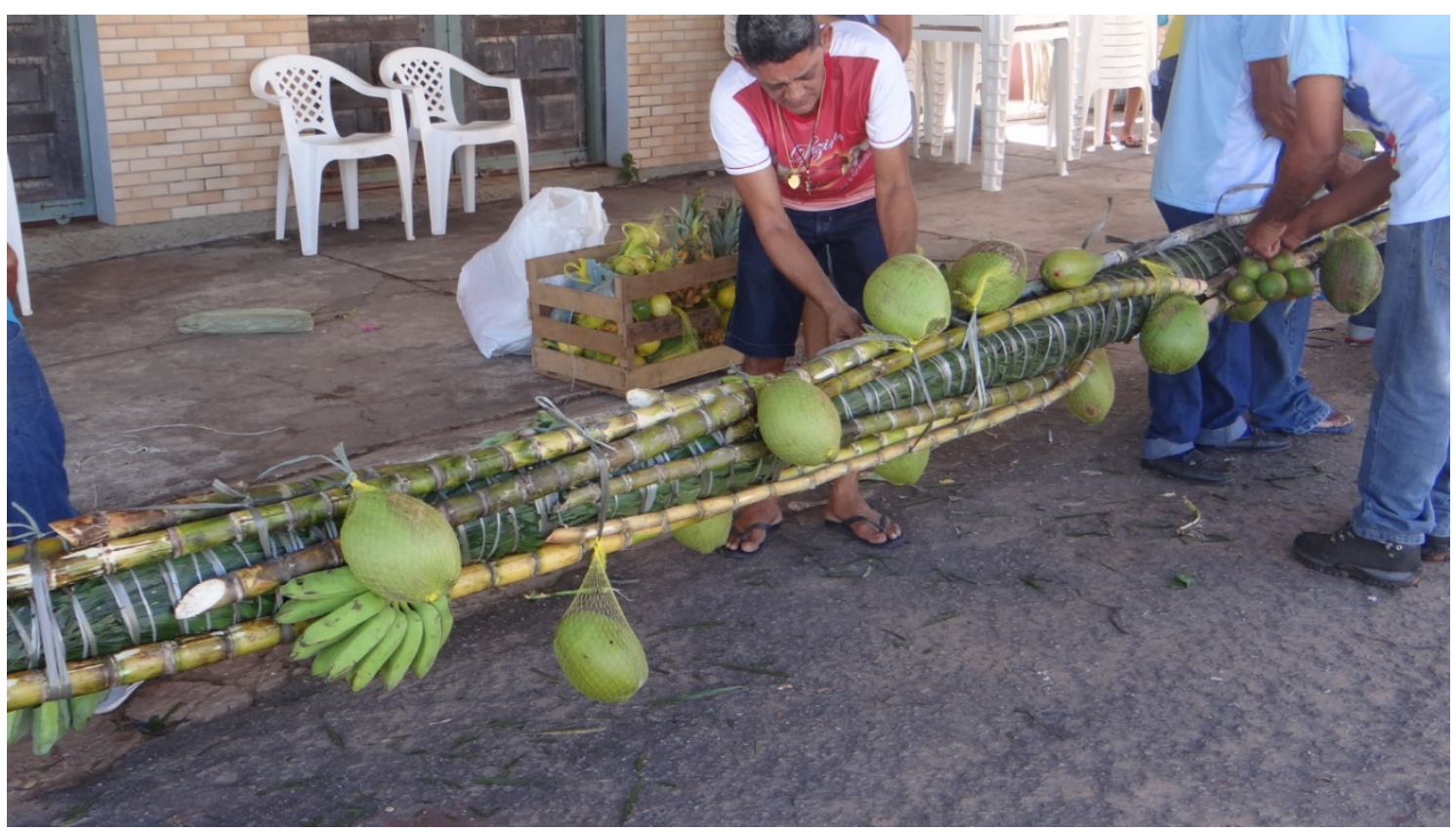




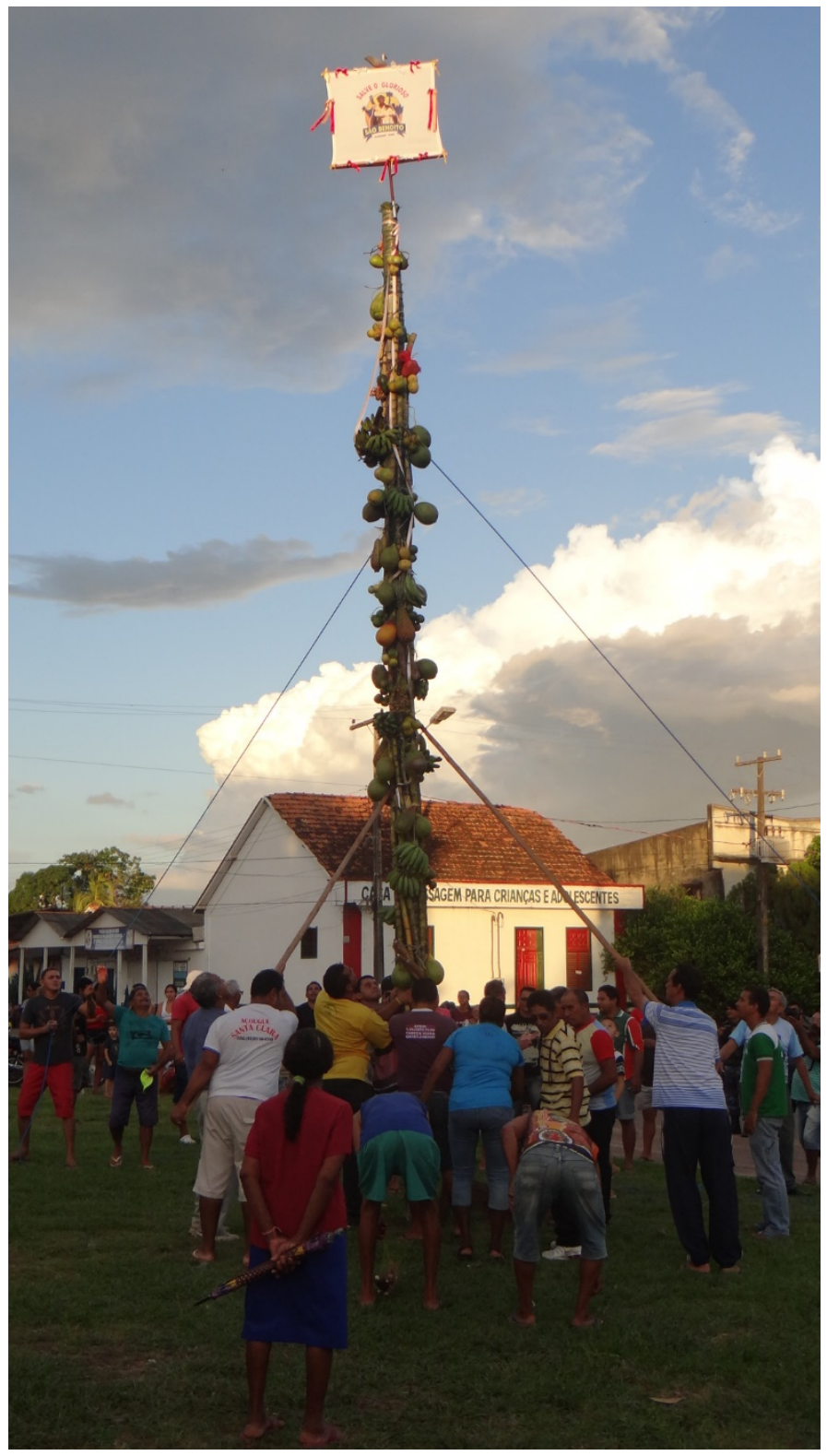



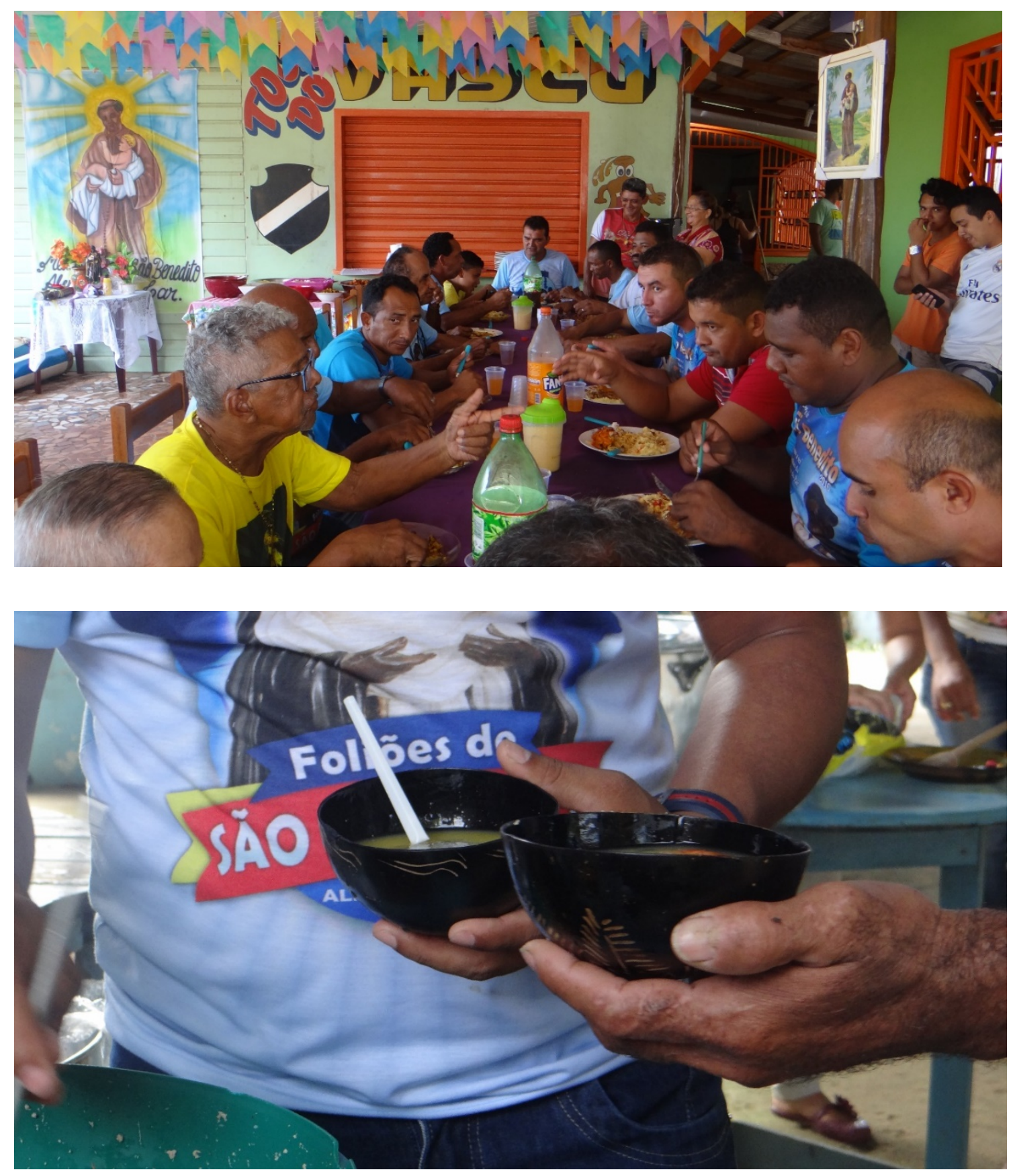
Comida, canto e dança: a circulação de dons na festa do gambá para São Benedito
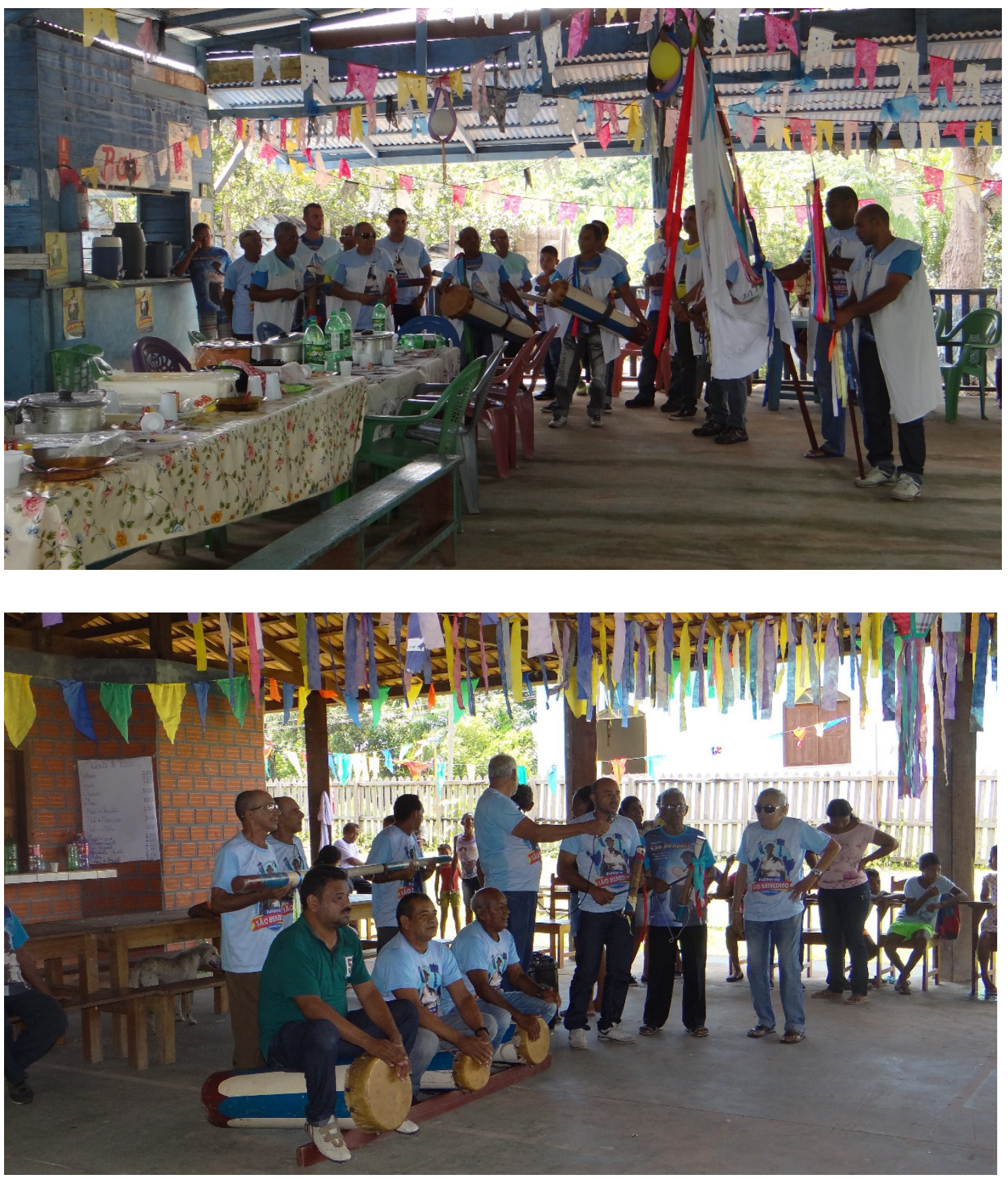

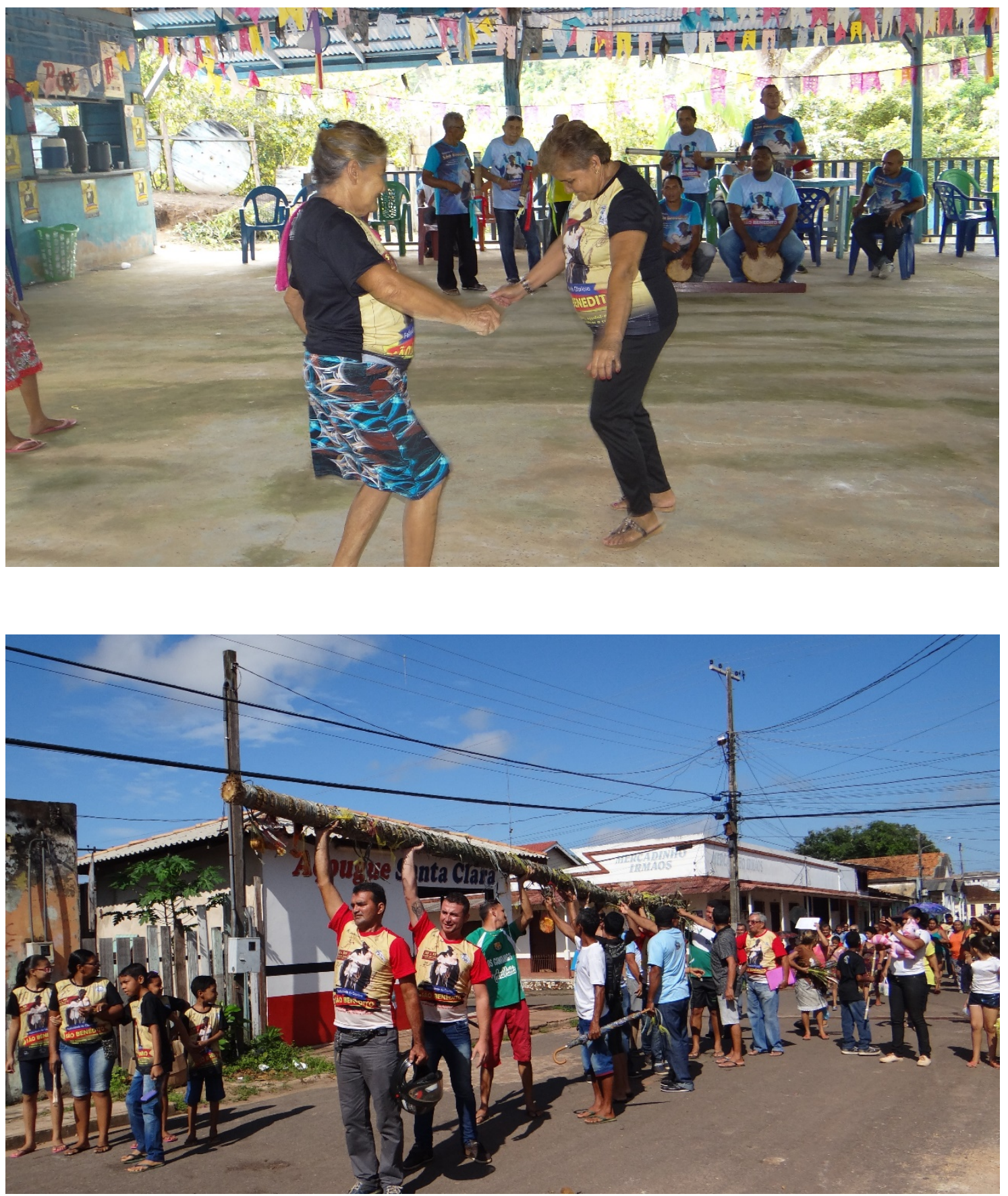
Comida, canto e dança: a circulação de dons na festa do gambá para São Benedito
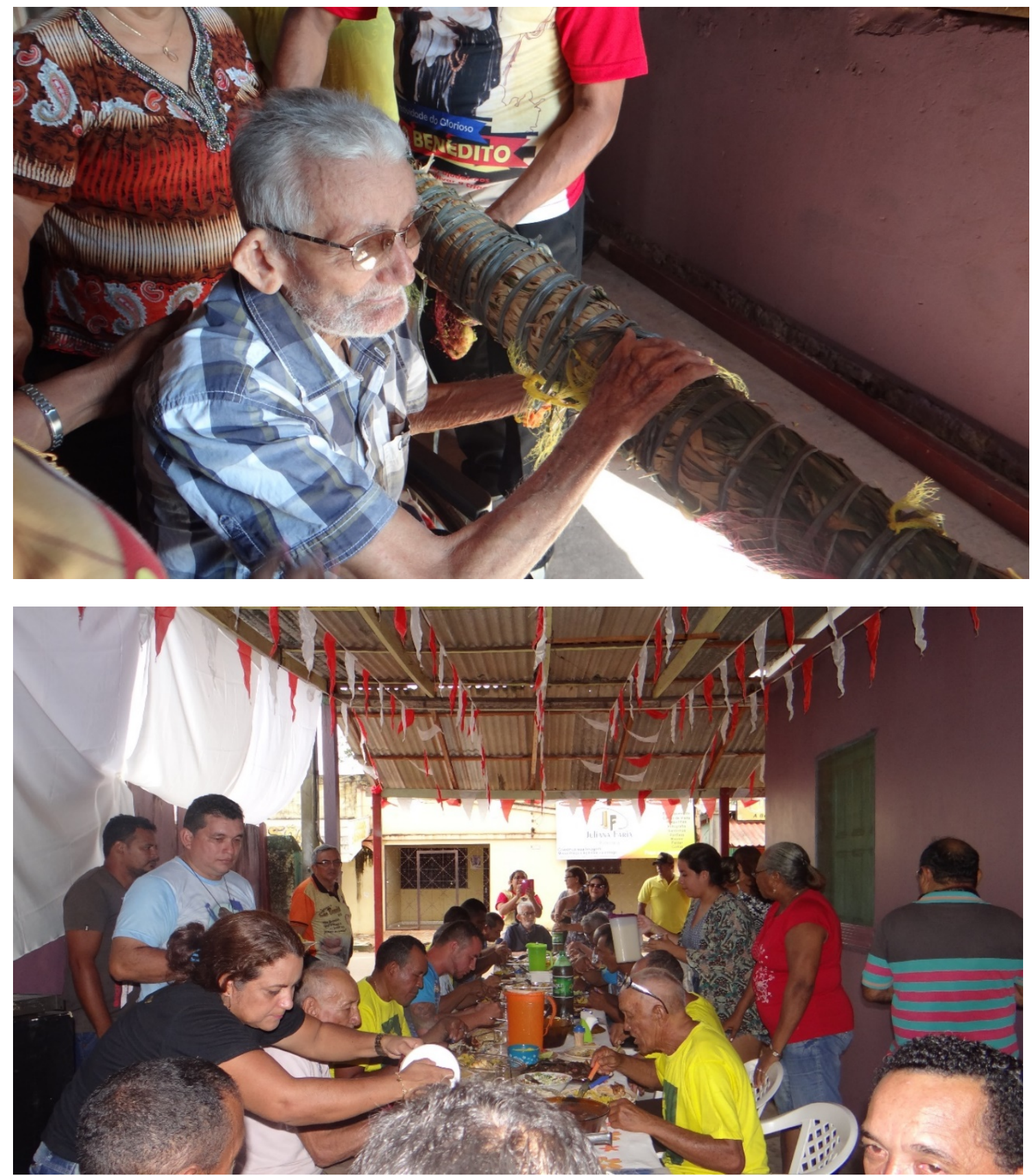

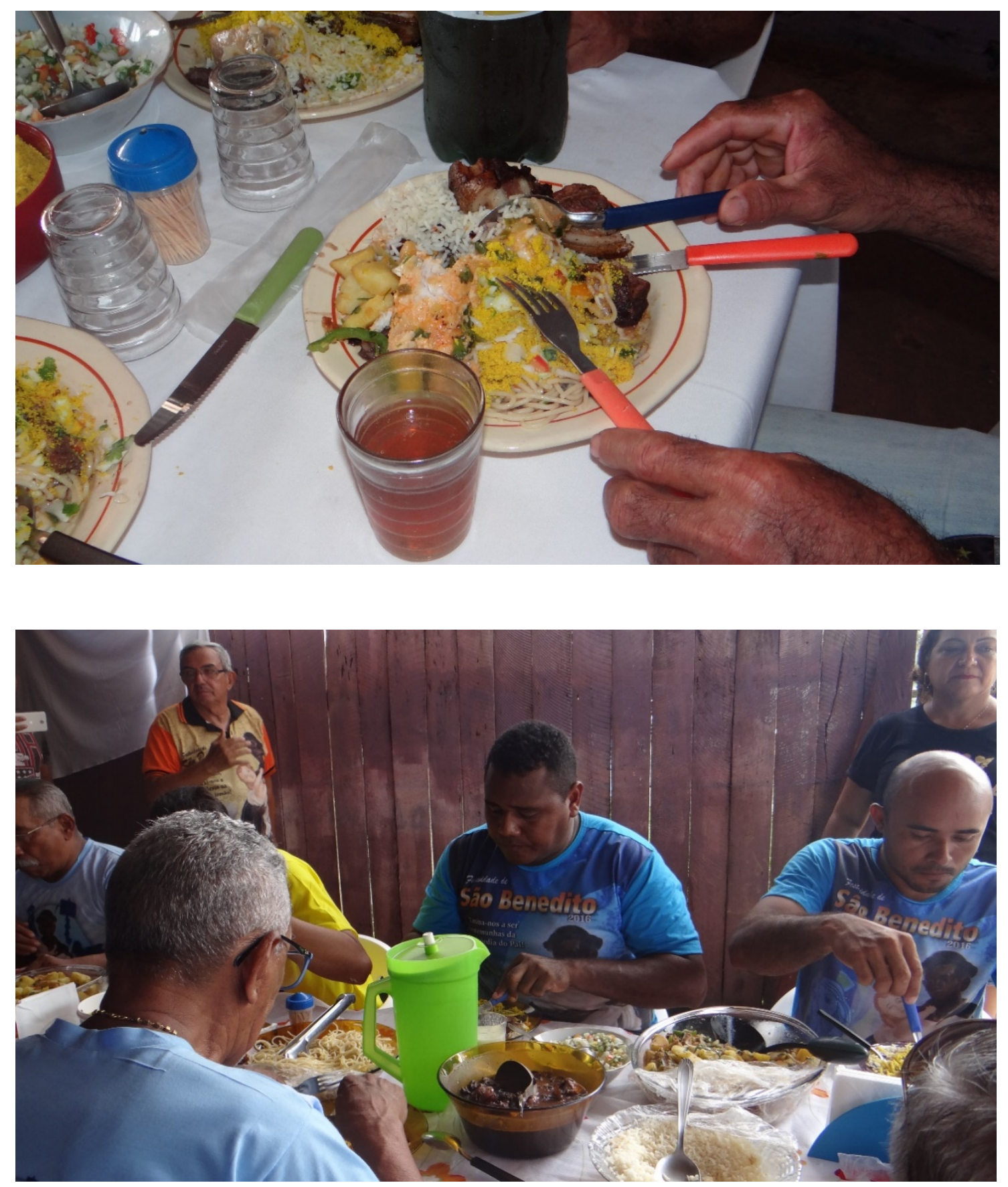
Comida, canto e dança: a circulação de dons na festa do gambá para São Benedito
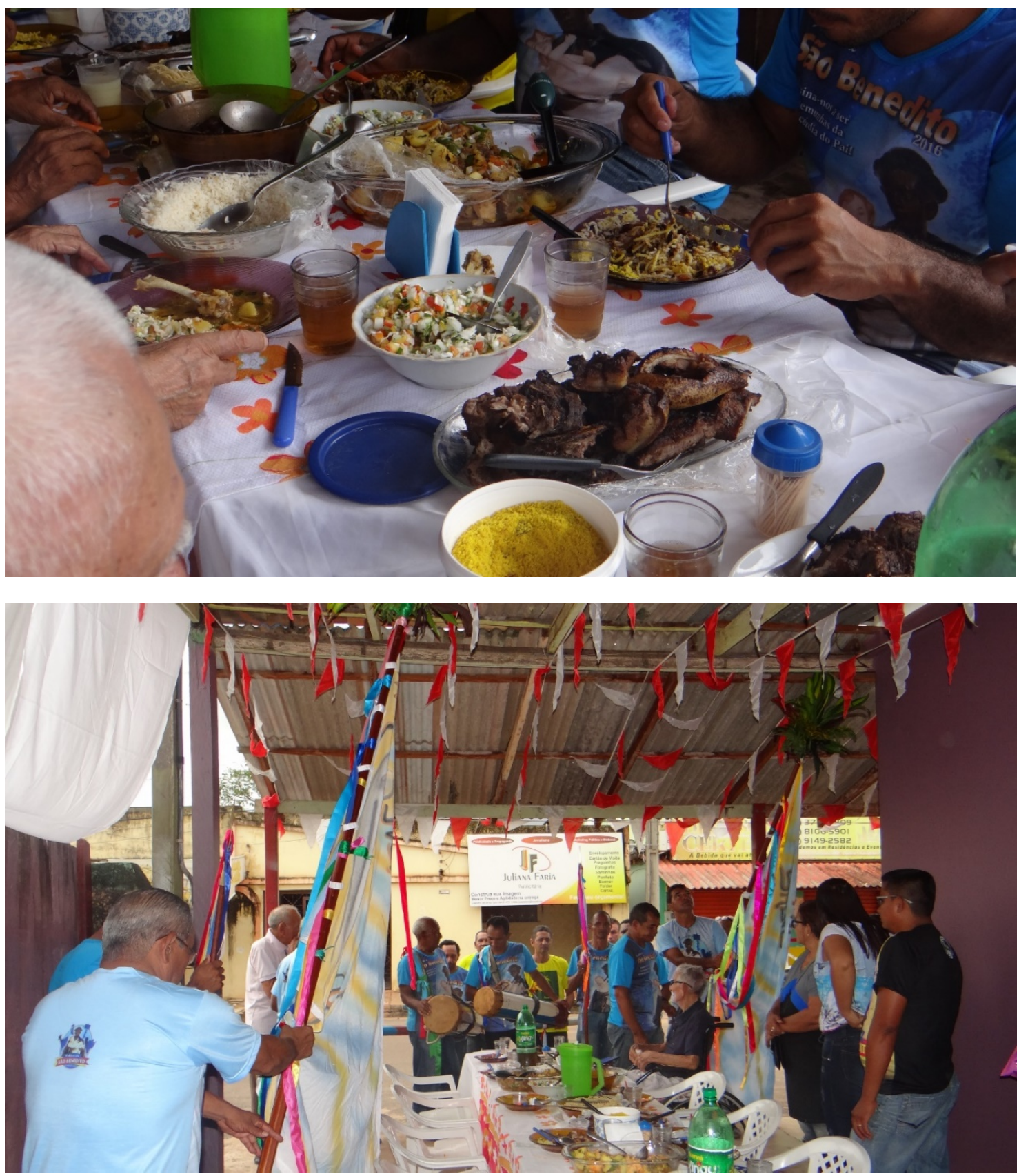




\section{REFERÊNCIAS}

ÁVILA, Cristian P. Os Argonautas do Baixo Amazonas. 2016. 423 f. Tese (Doutorado em Antropologia) - Programa de Pós-Graduação em Antropologia Social, Universidade Federal do Amazonas, Manaus, 2016.

BRAGA, Sérgio Ivan Gil. Festas religiosas e populares na Amazônia: algumas considerações sobre cultura popular. In: BRAGA, Sergio I. G. (Org.). Cultura popular, patrimônio imaterial e cidades. Manaus: Universidade Federal do Amazonas, 2007.

CAVAlCANTI, Maria Laura V. C.. Os sentidos no espetáculo. Revista de Antropologia, São Paulo, v. 45, n. 1, p. 37-78, 2002.

NOGUEIRA, Wilson. Festas amazônicas: boi-bumbá, ciranda e sairé. Manaus: Editora Valer, 2008.

VAZ FILHO, Florêncio A. A emergência étnica de povos indígenas no Baixo Rio Tapajós, Amazônia. 2010. Tese (Doutorado) - Programa de Pós-Graduação em Ciências Sociais Universidade Federal da Bahia, Salvador, 2010.

Recebido 08/08/2019

Aprovado 11/12/2019 